\section{AFFIXES FORMING PASSIVE VERBS IN BUGIS LANGUAGE}

\author{
Makkawaru \\ Universitas Gadjah Mada \\ Email:warumakka@gmail.com
}

\begin{abstract}
Abstrak. Masalah dalam penelitian ini adalah afiksasi bahasa bugis, yang dibatasi menjadi tiga submasalah yaitu; bentuk, fungsi dan makna afiks dalam bahasa Bugis. Afiksasi diuraikan dengan metode deskriptif dan berbentuk kualitatif. Sumber data berupa tuturan - tuturan dari penutur asli bahasa Bugis. Teknik pengumpulan data yaitu teknik wawancara lansung yaitu teknik pancingan, penunjukan aktifitas, penunjukan gambar dan studi dokumenter. Teknik analisis yang digunakan dalam penelitian adalah mentranskripsikan data kedalam bentuk tulisan, kemudian diklasifikasikan sesuai dengan masalah. Berdasarkan hasil analisis data yang sudah ada, hasil penelitian menunjukkan bahwa afiks dalam bahaa Bugis memiliki bentuk, fungsi, dan makna. Bentuk afiks dalam bahasa Bugis yaitu: Prefiks $\{$ ta- $\},\{$ ri- $\},\{$ na- $\}$, \{ripa- $\}$, afiks rangkap \{na-,-ngi\}, \{ri-,-eng\}, \{ri + aG- , -ang\}. Fungsi: mengubah kelas kata dan tidak mengubah kelas kata. Makna afiks pembentuk verba pasif bahasa Bugis yaitu: Prefiks \{ta-\}: Menyatakan kejadian yang tiba-tiba atau tidak sengaja, dan menyatakan perbuatan atau tindakan yang dikenai pekerjaan yang disebut pada kata dasar, \{ri-\}: Menyatakan perbuatan atau tindakan yang dikenai pekerjaan yang disebut pada kata dasar, \{na-\}: Menyatakan perbuatan atau tindakan yang dikenai pekerjaan yang disebut pada kata dasar, \{ripa-\}: Menyatakan makna kausatif. Makna afiks rangkap \{na-, -ngi\}: Menyatakan dijadikan seperti yang disebutkan pada bentuk dasar, \{ri- , -eng\}: Menyatakan perbuatan yang disebutkan pada bentuk dassar, \{ri- + aG- , ang\}: Menyatakan perbuatan yang disebutkan pada bentuk dasar.
\end{abstract}

Keywords: Afiks, Verba, Bentuk, Fungsi, Makna

\section{INTERFERENCE \\ Journal of Language, \\ Literature,and \\ Linguistics}

\section{E-ISSN: 2721-1835 \\ P-ISSN: 2721-1827}

\author{
Submitted : July $10^{\text {th }}, 2020$ \\ Accepted : August $6^{\text {th }}, \mathbf{2 0 2 0}$
}

Abstract. The problem of this research is the affixation of Bugis language, which is limited to three subproblems namely; affix form, function, and meaning in Bugis language. Affixation is described as descriptly and qualitatively. The data source is in the form of utterances from native speakers of the Bugis language. Data collection techniques are direct interview techniques, namely fishing techniques, the designation of activities, designation of images, and documentary studies. The technical analysis used in research is to transcribe data, then transcribe it into written form, then classified according to the problem. Based on the analysis of existing data, the results of the study show that the affixes in Bugis language have form, function, and meaning. The form of affixes in Bugis language are: Prefixes $\{\mathrm{ta}-\},\{\mathrm{ri}-\},\{\mathrm{na}-\}$, \{ripa-\}, double affixes $\{$ na -, - ngi\}, \{ri -, - eng $\},\{$ ri $+a G-$ - -ang\}. Function: changing the word class and not changing the word class. The meaning of affixes forming passive verbs in Bugis language is Prefix \{ta-\}: Stating a sudden or unintentional event, and stating an action that is subject to work referred to in the root word, \{ri-\}: Stating the action being taken work called the root word, \{na-\}: Stating the action that is subject to work which is called the root word, \{ripa-\}: States the causative meaning. Meaning of double affixes \{na-,-ngi\}: Stating is made as stated in the basic form, \{ri-, -eng\}: Stating the action mentioned in the basic form, \{ri- + aG-, ang\}: Stating the action mentioned in the basic form. 


\section{INTRODUCTION}

Every language that has its own grammatical structure is called Bugis language, both include phonological systems, morphology, and syntax. The language structure that talks about word forms are morphology. The morphological process is a way of forming words by connecting one morpheme with another morpheme (Samsuri, 1994: 190). Generally, language studies tend to analyze or explain linguistic features. From the mapping of its features, a language can be classified by its language patterns (Mantasiah et al., 2020).

The initial step that must be taken to analyze a language is to form language classes based on certain parameters, for example, parameters, word classes, word types, roles, and word functions in a construction. For example, a language based on the basic order of verb-subject-object (VSO) will (theoretically) find the type of language that correlates with prepositions, namely (1) VSO + Preposition, (2) VSO + non-preposition, (3) Non-VSO + Preposition and (4) non-VSO + non-preposition. For Greenberg (1986: 596) the likelihood of the patterns in (1) to (4) must be present in every subject. Greenberg developed a new systematic by taking into account the three elements or types and systems, which be together called the basic order. The basic sequence involves: (1) The relative sequence between subject, predicate, and object in a declarative sentence symbolized by $\mathrm{S}$ (subject), $\mathrm{V}$ (verb), and $\mathrm{O}$ (object), (2) adposition, i.e. in a language denoted by pr / po (preposition/position) and (3) the position of the noun attribute adjunctive, if the adjective precedes the noun, this sequence is denoted by AN If the noun precedes the adjective is represented by NA (Greenberg, 1989; 73-113 ).

Bugis Language is a Polisenia Malay language family that is used by more than four million people in 23 districts in South Sulawesi (Agus, 2009: 310). In the Bugis language, it is possible to form words by combining morphemes with other morphemes in this case, the process of affixation, namely the formation of affixes to the basic form. For example the word tabbukka 'open' is formed from the prefix $\{$ ta- $\}+\{$ buka) to tabbuka. There are quite a number of aspects that need to be examined. However, in this study, one aspect is described, namely affixes forming passive verbs in the Bugis language. To preserve the language and culture of this research area it is very important in the dissemination of information and language development, bearing in mind that research that addresses the problem of affixation forming passive verbs is still rare.

Based on the background above, the authors formulated the problem statement as follows: (a) What are affixes that function as affixes for making passive verbs in Bugis language?, and (b) How are the functions and meanings of affixes forming passive verbs in the Bugis language? In this study, the goal achieved is to describe the affixes forming passive verbs in the Bugis language, and describe the function and meaning of the affixes that form the passive verbs in the Bugis language.

In the affix research on the formation of passive verbs in the Bugis language, the author refers to scientific work related to this research. Scientific work that is used as reference material is as follows. Masyita (2013) under the title "Affixes forming verbs in the Sidrap dialect language", from FKIP Tadulako 
University. In his research, the researcher focused on the main issues of (1) what are affixes that function as verbs for the Bugis Sidrap dialect?, and (2) what is the function and meaning of the affix for the verbs for the Bugis Sidrap dialect? Researchers in this study describe the affixes forming verbs in the Sidrap dialect and the function and meaning of the affix for forming the Sidrap dialects. This study uses the listening method and proficient method, with tapping techniques, skillful engaging technique, and free engraving engraved listening techniques, fishing techniques, advance competent techniques, record, and note techniques. Then analyzed and presented with formal methods and informal methods. In the data analysis, the matching method and the distribution method are used.

Tupa (2013) with the title "Passive verb construction in Makassar language" from the language hall of the Province of South Sulawesi and the Province of West Sulawesi. The researcher in formulating the subject of his research focuses on (1) the characteristics of passive verbs in the Makassar language, (2) the affixes that form the passive verbs in the Makassar language, and (3) the form, distribution, function, and semantic meaning of the passive verbs in the Makassar language. The method used in this research is descriptive method with two data collection techniques namely, note-taking technique, and data processing and analysis techniques. The data used in this study were sourced from oral and written data.

From the two studies above, the author makes it as one of the references for his research because of similarities with the research topic. Like Masyita, and Nursiah both examined the verb-forming affixes of regional languages in South Sulawesi (Bugis and Makasaar), where Masyita focused on the characteristics, forms, distribution, functions, and meanings of the affixes forming verbs in the Sidrap dialect, while Nursiah is more specific to the affixes forming passive verbs in Makassar language.

\section{Verb}

Keraf in (Sugono, 7; 2003) revealed that to find a verb or not a word is to follow two procedures, namely (1) looking at the terms of the nominating form and in terms of word groups as a determining procedure. Next Moeliono (1981) determined verbs based on morphology (word form) and based on syntax (word group). Morphological markers are those that can follow slots that are filled with basic shapes. Whereas syntactic markers are used to show the characteristics of verbs from a syntactic angle.

Kridalaksana (1986: 51-58) added that verbs can be seen from several aspects, namely verbs (free, derived), number of arguments (transitive, intransitive), verb relationship with documents (active, passive, anti-active, antipassive), argument references, the interaction between arguments, and identification relations between the two arguments. Verbs have morphological characteristics, such as time, aspect, persona, or number (Kridalaksana, 1986: 176).

In connection with the interests of this study, derived verbs in the Bugis language are only discussed through affixation processes specifically in the formation of passive verbs. Passive Sentences are derivatives of active sentences 
that have a transitive predicate. Chaer (2002: 126) if the predicate is a single predicate and consists of one phrase, then the methods of interpretation used are:

1. Moving the active sentence object into the subject of a passive sentence.

2. Move the subject of an active sentence into the object of a passive sentence.

3. Change the form of the active verb me to be di.

4. Placing the word oleh as an optional marker between the predicate and the object of the actor.

In passive sentences, the relationship between the actor and the verb is very close so that it cannot be separated by other words. The rules that generally apply in the change of active form to be passive and interspersed with the word though, are not valid, and not all active verbs use the prefix me-. For pronouns I/II are located at the beginning of the verb in a passive sentence, while the third person is placed after the passive verbs di-.

The position of the subject, predicate, and object is very important in an active change to passive. Although not all active sentence objects can be subjects in passive sentences. In the book Jos Daniel Parera (1991: 159) explains about the postulates of the promotion of subjects, among others:

1. Subject-object analysis can only be used in languages that recognize activepassive construction.

2. The subject is a matter of promotion of a place in front of the predicate.

3. Complement cannot be promoted to the subject.

4. Complement can be promoted as an object with the morphological changes of predicate verbs that make it possible.

5. The direct object of active sentences can be promoted to be subjects in passive sentences.

6. Complement which has been promoted to be a direct object in the active sentence can be promoted to be the subject in the passive sentence.

7. The object is always located to the right of the predicate active sentence as the scales of the subject.

8. Promotional demands occur in active and passive sentences; subject promotion; promotion of complement becomes an object; only active object sentences are promoted to be subjects in passive sentences.

\section{RESEARCH METHOD}

The object of research in this study is the form of affixation contained in the complete dictionary Bugis - Indonesian Language. The research method used is qualitative, the research method used to make a picture of a situation or event so that this method intends to use basic data accumulation (Soeharto, 1993: 79).

The steps taken in this study are three stages, namely (1) the stage of data collection, (2) the stage of data analysis, and (3) the stage of presentation of results 
and data, (Sudaryanto 1992: 57) Data collection methods used in this study are interview and recording techniques. The recording technique was carried out using video conversations by the community in using Bugis language. Interviews were conducted with the community regarding affixation used related to affixation used in the Bugis language. Interviews were conducted with the help of written instruments and recording devices.

The steps to analyze the data used by researchers are:

1. Recording Bugis language affixation data based on the results of recorded interviews,

2. Describing the Bugis language affixation forms,

3. Describing the Bugis language affixation functions,

4. Defining the meaning of affixation contained in the Bugis language, and

5. Reporting the results of the research.

Juliarsa in Moleong (2004: 103) is the process of sequencing data, rationalizing it into a basic pattern, category, and description unit. The method used in presenting the results of data analysis used is the formal and informal methods. The formal method is the method of presenting the results of data analysis using symbols such as the plus sign (+), quotation marks ("), minus sign (-), parentheses elbows ([ ]), curly braces ( ( ) ) and others. While the informal method is a method of presenting the results of data analysis conducted to use writing or ordinary words.

\section{RESULT AND DISCUSSION}

According to Abdul Chaer affixation is the process of affixing in a basic form. In this process involved (1) basic elements or basic forms, (2) affixes, and (3) grammatical meaning produced. The type of affixes that form passive verbs in Bugis can be seen based on the position of the affixes attached to the basic form. In this case, an affix consisting of prefixes, infixes, suffixes, confixes, and double affixes. However, in this study, the authors have not found infix, suffix, and confix in the formation of passive verbs in the Bugis language. for more details can be seen in the following description.

1. PREFIXES

The prefix is the process of forming words by adding prefixes in front of the basic words and writing them together.

a) $\{$ ta- $\}$

The prefix $\{$ ta- $\}$ is attached to the basic form of nouns, verbs and, adjectives, $\{\mathrm{ta}-\}$ functions to form an unintentional passive verb. The prefix $\{\mathrm{ta}-\}$ can appear in the form taG- or tar-. The prefix $\{\mathrm{ta}-\}$ are allied with taG- if they are attached to the root of the initial consonant / b, c, d, g, k, j, l, p, s, t /.

e.g.:

- $\{\operatorname{taG}-\}+\operatorname{bukkak}(\mathrm{V}) \rightarrow \operatorname{tabbukkak}(\mathrm{V})$ 


\begin{tabular}{|c|c|c|c|c|}
\hline & & 'buka' & & 'terbuka' \\
\hline \multirow[t]{2}{*}{ - $\{\mathrm{taC}-\}$} & + & calak (N) & $\rightarrow$ & taccalak (V) \\
\hline & & 'kunci' & & 'terkunci' \\
\hline \multirow[t]{2}{*}{ - $\left\{\mathrm{taG}_{-}\right\}$} & + & gala (N) & $\rightarrow$ & taggala (V) \\
\hline & & 'pengait' & & 'terkait/tersangkut' \\
\hline \multirow[t]{2}{*}{ - $\left\{\mathrm{taG}_{-}\right\}$} & + & kajennek (A) & $\rightarrow$ & takkajennek (V) \\
\hline & & 'tegung' & & 'tertegung' \\
\hline \multirow[t]{2}{*}{ - $\{\mathrm{taG}-\}$} & + & jellok (V) & $\rightarrow$ & tajjellok (V) \\
\hline & & 'gelincir' & & 'tergelincir' \\
\hline \multirow[t]{2}{*}{ - $\left\{\mathrm{taG}_{-}\right\}$} & + & lemmek (V) & $\rightarrow$ & tallemmek (V) \\
\hline & & 'tanam' & & 'tertanam' \\
\hline \multirow[t]{2}{*}{ - $\left\{\mathrm{taG}_{-}\right\}$} & + & pali (v) & $\rightarrow$ & tappali (V) \\
\hline & & 'putar' & & ‘terputar’ \\
\hline \multirow[t]{2}{*}{ - $\{\mathrm{taG}-\}$} & + & sakkak (V) & $\rightarrow$ & tassakkak (V) \\
\hline & & 'sangkut' & & 'tersangkut' \\
\hline - $\{$ taG- $\}$ & + & $\begin{array}{l}\text { tahang }(\mathrm{A}) \\
\text { 'tahan' }\end{array}$ & $\rightarrow$ & $\begin{array}{l}\text { tattahang }(\mathrm{V}) \\
\text { 'tertahan' }\end{array}$ \\
\hline
\end{tabular}

The prefix $\{$ ta- $\}$ becomes tar- if it is attached to the root word with the initial / u / phoneme.

e.g.:

- $\{\operatorname{tar}-\}+\operatorname{uki}(\mathrm{v}) \rightarrow \operatorname{taruki}(\mathrm{V})$

'tulis' 'tertulis'

As for the meaning contained in the prefix $\{t a-\}$ that is to state a sudden or accidental event, and to state an action which is subject to work referred to in the root word.

e.g.:

- /lanatta tejjellok ri wennik elek e/l 'kemarin anak kamu tergelincir'

- //tallemmek ki ajena// 'kaki dia tertanam'

- //taruki ki asengmu ri sengnge// 
b) $\{\mathrm{ri}-\}$

'Nama kamu tertulis diabsen'

The prefix \{ri-\} attaches to the basic form of verbs. The prefix function \{ri-\} is as a passive verb constructor. The prefix \{ri-\} does not change form if it is attached to the root word.

e.g.:

- $\{\mathrm{ri}\}+$ inreng $(\mathrm{V}) \rightarrow$ riinreng $(\mathrm{V})$

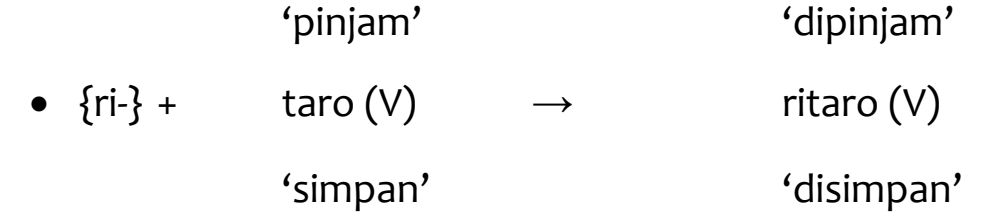

The meaning contained in the prefix $\{\mathrm{ri}-\}$ is to state the action which is subject to work referred to in the root word.

e.g.:

- // bok ku riinrengi sibawakku // 'Buku saya dipinjam teman saya'

- /lipak na amma' ku ritaro ri tase na// 'sarung ibu saya disimpan ditasnya'

- //iko pura ritaro ri laleng atena/l 'engkau sudah tersimpan di hatinya.

c) $\{$ na- $\}$

The prefix \{na-\} is attached to the basic form of verbs and nouns. The prefix $\{n a-\}$ in the affixing process is a prefix that does not change in shape when it is attached to the basic form of verbs and nouns.

e.g. :

\begin{tabular}{|c|c|c|c|c|}
\hline $\begin{array}{l}\text { - }\{\text { na- }\} \\
\text { - }\{\text { na- }\}\end{array}$ & + & $\begin{array}{l}\text { alututu (v) } \\
\text { 'sayang' } \\
\text { gajang }(\mathrm{N}) \\
\text { keris' }\end{array}$ & $\rightarrow$ & $\begin{array}{l}\text { naalututu (V) } \\
\text { 'disayang' } \\
\text { nagajang (V) } \\
\text { 'ditikam' }\end{array}$ \\
\hline
\end{tabular}

From the above data, it is known that the prefix \{na-\} which distributes with the basic form of verbs and nouns, which functions to form passive verbs. As for the meaning contained in the prefix \{na-\}, which is to state action or action which is subject to work referred to in a root word.

e.g. :

- //ia' naalututui ambok ku// 'saya disayang oleh Ayahku'

- // nagajang annrinna// 
'ditikam adiknya'

- //naalututui la'deki pole tomatoatta//

'kamu sangat disayang oleh orangtuamu'

d) $\{$ ripa- $\}$

The prefix \{ripa-\} attaches to the basic nouns, and functions as passive verbs. If the prefix ripa- starts with vowel / i / then it doesn't change.

e.g. :

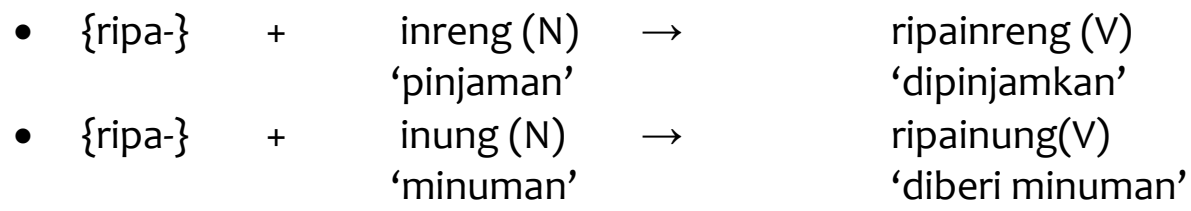

The prefix ripa- with phonemes / b /, / d /, / j/, and / g / gets phonemes / $/$ at the end.

e.g. :

\begin{tabular}{|c|c|c|c|c|}
\hline - $\quad\{$ ripa- $\}$ & + & beddak $(\mathrm{N})$ & $\rightarrow$ & ripakbaddak (V) \\
\hline & & 'bedak' & & 'diberi bedak' \\
\hline$\{$ ripa-\} & + & dua (N) & $\rightarrow$ & ripadua(V) \\
\hline & & 'dua' & & 'diduakan’ \\
\hline$\{$ ripa-\} & + & guna $(\mathrm{N})$ & $\rightarrow$ & ripakguna (V) \\
\hline - $\{$ ripa- $\}$ & + & 'janci (N) & $\rightarrow$ & $\begin{array}{l}\text { ripakjanci (V) } \\
\text { 'diberi janji' }\end{array}$ \\
\hline
\end{tabular}

The prefix ripa- in the basic form that starts with phonemes / $\mathrm{p} /, / \mathrm{k} /, \mathrm{c} /$, / s $/, / \mathrm{m} /, / \mathrm{n} /, / \tilde{\mathrm{n}} /$, and $/ \mathrm{n} /$ then the phonemes become a gemination.

e.g. :

- $\{$ ripa- $\}+\operatorname{caji}(\mathrm{N}) \quad \rightarrow \quad \operatorname{ripaccaji}(\mathrm{V})$

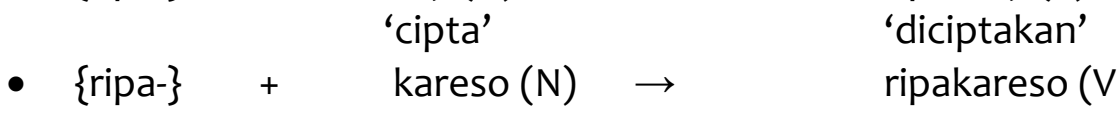

'usaha' 'dijadikan seseorang

bekerja'

The meaning of the prefix \{ripa-\} states the causative meaning.

e.g. :

- /lakkalang e ripancaci ri Allataala//

'akal diciptakan oleh Allah SWT'

- // ripakkareso ka ri bola e// 
'saya dibuat bekerja dirumah'

- //idi maneng ripakjanci pole gubernur//

'kami semua diberi oleh gubernur'

\section{DOUBLE AFFIXES} suffixes.

Double affixes include prefixes with suffixes or duplicate prefixes with

(a) $\{$ na-...-ngi $\}$

$$
\begin{aligned}
& \text { \{na-...-ngi }+ \text { aggeppuang }(\mathrm{V}) \quad \rightarrow \quad \text { naaggeppuangngi }(\mathrm{V}) \\
& \text { 'membanting' 'dibantingkan' }
\end{aligned}
$$

e.g. :

//naaggeppuangngi pole anrinna//

'dia dibantingkan pintu oleh adiknya'

From the above data, it is known that the double affixes \{na-... -ngi\} which are distributed with the basic form of verbs function to form passive verbs in the form of transitive sentences. The meaning contained in the double affix \{na- ... -ngi\} that is made as mentioned in the basic word.

(b) $\{$ ri-...-eng $\}$

$$
\begin{aligned}
& \{\text { ri-...-eng }\}+\text { jellok }(\mathrm{V}) \quad \rightarrow \quad \text { rijellokeng }(\mathrm{V}) \\
& \text { 'tunjuk' 'ditunjukkan' }
\end{aligned}
$$

e.g. :

//rijellokengngi waju pole bapakna//

baju itu ditunjukkan oleh ayahnya

$$
\begin{aligned}
& \text { \{ri-...-eng\} }+\quad \text { akke'rennung }(\mathrm{A}) \quad \rightarrow \quad \text { riakke'rennungeng }(\mathrm{V}) \\
& \text { 'gembira' 'digembirakan' }
\end{aligned}
$$

e.g. :

//iya' riakke'rennungeng'i pole ri sibawakku//

'saya digembirakan oleh teman saya'

The double affix \{ri-... -eng\} has the function of forming passive verbs that state the meaning of action. The double affix \{ri-... -eng\} does not change if the basic form it follows has the final / $\mathrm{k} /$ and / $\mathrm{\eta} /$ pattern. The phonemes / $\mathrm{r} / \mathrm{s} / \mathrm{s} / \mathrm{in}$ double affixes $\{$ ri- ... -eng $\}$ if the end of the vowel is long, and morpheme $\{-ə \eta\}$ in the confix $\{$ ri- ... - əワ\} get the addition of the phoneme $/ \eta /$ if the basic shape is followed -this has the final short vowel tone. The meaning of double affix \{ri-... -eng\} states the actions mentioned in the basic form. 
(c) $\{$ ri + aG-...-ang $\}$

$\{$ ri + aG-...-ang $\}+\underset{\substack{\text { Bampa }(\mathrm{N}) \\ \text { 'pukul' }}}{\rightarrow} \quad \begin{aligned} & \text { riabbampang }(\mathrm{V}) \\ & \text { 'dipukulkan' }\end{aligned}$

e.g. :
//riabbampangan'l awo ipul pole ri tomatoanna// 'Ipul dipukulkan bamboo oleh orangtuanya'
$\{$ ri + aG-...-ang $\} \quad+\quad$ pa'balu $(\mathrm{N}) \quad \rightarrow \quad$ riappa'balukang $(\mathrm{V})$ 'penjual' 'diperjualkan'

e.g. :

//de' riappa'balukang ayyede wajue// 'baju ini tidak diperjualkan'

The double affix $\{$ ri + aG -...- ang $\}$ functions to form a passive verb, this affix changes shape according to the initial phoneme of the word if the prefix a- is attached to the root of the initial vowel / a, i, u, è, o, e /, then the prefixes are numbered $\mathrm{aN}-, \mathrm{aG}-$, and ar, and prefix $\mathrm{a}$ - is attached to the root of the initial consonant phoneme, the morpheme is aG- if attached to the root of the initial consonant / b, c, d, g, k, l, m, n, ng, ny, p, s, t/. The meaning of this affix is to state the actions mentioned in the basic form.

\section{CONCLUSION}

Based on the research conducted, the following conclusions are obtained:

1. The form of affixes that form passive verbs in Bugis language consists of:

a. Prefixes $\{$ ta- $\},\{$ ri- $\},\{$ na- $\}$, \{ripa- $\}$.

b. Double affixes $\{$ na -, - ngi $\},\{r i-,-$ eng $\},\{r i+a G-,-a n g\}$.

2. Function: changing the word class and not changing the word class.

3. The meanings of affixes that form passive verbs in Bugis language are:

a. The meanings of prefixes

1) \{ta-\}: Stating a sudden or unintentional event, and stating an action which is subject to work referred to in the root word.

2) \{ri-\}: Stating an action that is subject to work referred to in the root word.

3) \{na-\}: Stating an action which is subjected to work referred to in the root word.

4) \{ripa-\}: Stating the causative meaning.

b. The meanings of double affixes

1) $\{$ na-, -ngi\}: Declaring made as stated in the basic form.

2) $\{$ ri-, -eng\}: Stating the action mentioned in the basic form.

3) $\{$ ri- + aG-, -ang\}: Stating the action mentioned in the basic form. 
4. Passive first-person actors (me, you), second-person actors (us, you), and thirdperson actors (man/woman, that) do not influence morphological changes in the passive verb form.

\section{REFERENCES}

Agus, N. (2009) “Kajian Tipologis Terhadap Urutan Konstituen Bahasa Bugis: Kasus Pada Klausa Verbal Aktif”. Sawerigading. Vol. 15, No. 3, . pp. 309-320.

Chaer, A. (2002). Pengantar Semantik Bahasa Indonesia. Jakarta: Rineka Cipta.

Greenberg, J.H. (1986). Universal of Language. England: The MIT Press Cambridge,Massachusetts, and London.

Juliarsa, dkk (2014). “Afiksasi Bahasa Dayak Keninjal”. Pontianak: FKIP Untan.

Mantasiah, R. (2020). Semantic Feature Analysis Model: Linguistics Approach in Foreign Language Learning Material Development. International Journal of Instruction, 13(1), 185-196.

Masyita (2013). “Afiks pembentuk Verba Bahasa Bugis Dialek Sidrap”.Palu : Bahasa dan Sastra. Vol2, No 2

Parera, J.P. (1997). Linguistik Edukasional Metodologi Pembelajaran Bahasa Analisis Kontrastif Antarbahasa Analisis Kesalahan Berbahasa. edisi II. Jakarta: Erlangga.

Kridalaksana, H. (1986). Kamus Linguistik: Edisi keempat. Jakarta: Gramedia.

Moeliono, A.M. (1981). PengembanganDan Pembinaan Bahasa: AncanganAlternatif di Dalam PerencanaanBahasa. Jakarta: PenerbitDjambatan

Samsuri. (1994). Analisa Bahasa. Jakarta: Penerbit Erlangga.

Soeharto, B. (1993). Petunjuk praktis mengenai pengertian fungsi bimbingan dan cara penulisan karya ilmiah (makalah, skripsi, thesis) ilmu sosial. Bandung : Tarsito

Sudaryanto. (1993). Metode dan Aneka Teknik Analisis Bahasa. Yogyakarta: Duta Wacana Universty.

Sugono, D. (2003). "Verba Taktransitif Dalam Bahasa Sunda. Jakarta: Pusat Bahasa Departemen Pendidikan Nassional.

Tupa, N. (2016). Konstruksi Verba Pasif Dalam Bahasa Makassar (Passive Verb Construction in Makassarese Language). SAWERIGADING, 20(3), 423-431. 